\title{
The Socioecological Fix: Fixed Capital, Metabolism, and Hegemony
}

\author{
Michael Ekers and Scott Prudham
}

\section{QUERY SHEET}

This page lists questions we have about your paper. The numbers displayed at left can be found in the text of the paper for reference. In addition, please review your paper as a whole for correctness.

Q1. Au: Please provide a page number for this quotation from O'Connor 199

Q2. Au: Please include any Funding details to be formally acknowledged in this article.

Q3. Au: Maher 2008 is not cited in text. Please either add a citation there or delete the entry here

Q4. Au: Please provide full mailing address for Ekers

Q5. Au: Please provide full mailing address for Prudham

\section{TABLE OF CONTENTS LISTING}

The table of contents for the journal will list your paper exactly as it appears below:

The Socioecological Fix: Fixed Capital, Metabolism, and Hegemony

Michael Ekers and Scott Prudham 


\section{The Socioecological Fix: Fixed Capital, Metabolism, and Hegemony} ow do we understand the enrollment of landscapes and biophysical processes within means of staving off entangled political economic, cultural, and ecological crises of capital accumulation? In the first of these two companion articles we assessed question and for developing the notion of socioecological fixes to crises of overaccumulation. We reviewed the vital contributions that Harvey (1981, 1982, 1985b, 1985c, 2001, 2003a) made to formulating the the idea of sunk capital formation in the context of spatial fixes as metabolic processes entailing the production of socioecological transformations as well as the production of space. We also emphasized the need

35 for more attention to the political and cultural dynamics at play within spatial fixes. Turning to Smith (1996, 1998, 2007, [1984] 2008), we argued that his account of the production of nature provides a way of thinking about the metabolism of spatial fixes and Smith's account of the integrated production of space and nature was uneven and that he did not systematically explore contradictions within the capitalist production of nature, contradictions that are both 45 political and ecological. We turned to and looked to extend the work of O'Connor (1997) and feminist thinkers such as Katz (2001) to more fully explore questions of crises (and spatial fixes) in an explicitly socioecological register.

In this companion article, we focus more specifically on fixed capital formation within socioecological fixes. We seek to deepen our argument regarding the metabolic character of fixed capital formation, attending at the same time to how, why, and by whom socioecological landscapes and processes are transformed in response to conditions of overaccumulation and broad socioecological crises. We approach socioecological fixes in ways that attend to the particular conditions, forces, and relations of production as these are developed through broader conjunctures of political and cultural influences that in turn are tied to questions of legitimacy. This article then systematically explores connections between fixed capital and hegemony as they pertain to socioecological fixes.

Throughout the article we suggest that understanding the category, constitution, and functioning of fixed capital in particular is essential to understanding socioecological fixes; this is the first pillar of the article. Following Harvey, we return to Marx's ([1858] 1973, [1885] 1978) Capital, Volume II and the Grundrisse to explore in more detail the relationship between "nature" and fixed capital formation. As Harvey argued (and as we reviewed in the first article), fixed capital (along with enduring forms of the 
consumption fund) comprises the geographically explicit infrastructure we associate with spatial fixes, absorbing surplus value and accelerating the circulation of commodity capital through space. Fixed capi-

80 tal is also, however, a key avenue by which capital accumulation works in and through biophysical processes in the formation of specific ecological regimes (Moore 2011) of accumulation. We emphasize the role of capitalist crises in triggering the formation of 85 fixed capital, as overaccumulated capital is, and can be, redirected from the primary circuit of accumulation (production for direct consumption) to secondary circuits (including, e.g., forms of the built environment that enable the production, circulation,

90 and consumption of commodities while underpinning social reproduction) and tertiary circuits (e.g., investments in science, education, and social reproduction more broadly). We emphasize, however, the ways in which these dynamics link fixed capital formation to

95 the creation of both the socioecological conditions of production and also shape the specific ways in which the circulation of capital takes place via, and is constituted by, historically and geographically differentiated biophysical processes. We argue, broadly

100 speaking, that the material processes and throughputs embodied in and metabolized by fixed capital formation are important to understanding the dynamics of fixed capital formation as well as the socioecological specificity of actual fixes.

105 Although an emphasis on fixed capital represents one of the foundations of our argument, exploring the relationship between this type of capital as infrastructure and the question of hegemony is the second pillar of our argument. As we suggested in

110 our first article, accounting for the so-called extraeconomic dynamics of the socioecological fix requires developing themes less emphasized by Harvey and Smith. For this reason, in the second half of this article, we turn to Gramsci's writings.

115 We argue that not only are forces, conditions, and relations of production secured in part through fixed capital investments, but also that large-scale fixed capital formation forms a foundation of capitalist hegemony, comprising the terms on which 120 the legitimacy of specific social formations (including class structures and questions of difference) and particular institutions (including states) as well as capitalism writ large is negotiated. In this respect, we make the case that fixed capital formation in 125 the guise of various socionatures must be understood as an economic and extraeconomic, material and ideological process with valences that fuse capital accumulation, socioenvironmental change, and the conditions and experiences of everyday life.

\section{A Brief Comment on Method}

A comment on our method is necessary. In our political ecological rendering of Harvey's theory of the spatial fix, in many respects, we follow Harvey's own method. In his Companion to Marx's Capital, Volume 2, Harvey (2013) wrote, "If, as I think we should be, we are interested in integrating theories of the production of space into Marx's general theory of capital accumulation, then it must primarily be through systematic extension of the materials assembled both [in Capital, Volume II] and in the Grundrisse on the formation of fixed capital embedded in the land" (125). Harvey's comments also hold for how we account for the socioecological character of spatial fixes and the production of nature via the establishment of fixed capital in land. So we, too, turn to Marx.

In addition, however, we seek to bring Marx's theorization of fixed capital (complemented by Harvey's elaborations) into closer conversation with Gramsci's $(1971,1995)$ account of hegemony and with relatively more recent (and to our mind more aligned) attempts to understand the ideological dimensions and significance of fixed capital, infrastructure, and landscapes (D. Mitchell 1996, 2000; Kaika and Swyngedouw 2000; Gandy 2002; Ekers 2009, 2015; Loftus 2012; Swyngedouw 2015). ${ }^{1}$ This somewhat unruly set of intellectual alliances emphasizes the "historical" (and geographical) in historical materialism, prioritizing the historicity of specific socionatural processes and relations (including how we come to "know them"). To be historicist in method entails engaging in a process of moving back and forth between the "abstract" and the "concrete" (Sayer 1987; Buttigieg 1990). The concrete, in part, represents a point of departure for Marx, but through a process of abstraction (i.e., the practice of thinking), he argued that we begin to elaborate on the particular relations and forces that constitute historical and geographical conjunctures. As Marx ([1858] 1973) explained: "The concrete is concrete because it is the concentration of many determinations, hence unity of the diverse. It appears in the process of thinking, therefore, as a process of concentration, as a result, not as a point of departure" (100-01). A historicist approach, which was at the core of Gramsci's method (see Buttigieg 1990; Morton 2007; Thomas 2009) then, is to account for the "many 
determinations" as they are specifically and in actuality related to one another, to explain their role in constituting the worlds we inhabit.

Although our presentation in this piece is rather

180 formalistic, our arguments reflect and are motivated by concrete changes in the contemporary political ecology of capitalism. We noted in the first article, for instance, the salience of the fact that India is expected in some quarters to be generating close to 60 percent

185 of its electricity from non-fossil-fuel energy sources by 2027. This trend, moreover, is being propelled by state coordination of private investments in new energy infrastructure that is explicitly aimed at changing the socioecological foundations of the Indian energy sys-

190 tem (Safi 2016). As McCarthy (2015) argued, the basic foundations of the theory of the spatial fix are highly salient to understanding large-scale infrastructure conversions, including a transition to renewable energy, yet these forms of spatial fix need to be under-

195 stood also as socioecological fixes in ways not anticipated by existing theoretical accounts. Although we can only gesture to transformations such as these, our theoretically inflected reflections are motivated very much by these concrete developments.

\section{Fixed Capital as a Metabolic Process}

For Harvey (1981, 1982, 1985b, 1985c, 2001), spatial fixes provide avenues for reproducing the conditions of capital accumulation and attenuating crisis tendencies via "fixing" capital in particular spatial

205 configurations; specific spatial fixes might be intensive and centralizing or extensive and decentralizing in orientation, or they might be both (Harvey 1978, 1981, $1982,1985 b, 1985 c, 2001,2003 a)$. Whether it is the intensive and centralizing or extensive and decentral-

210 izing moment of a fix, the formation of fixed capital is central in giving rise to the production of nature in the guise of spatially explicit infrastructure. Moreover and as we discuss in more detail later, large-scale fixed capital formation can function as a sink for surpluses

215 of overaccumulated capital while soaking up otherwise idle labor and productive capacity, thus having the effect of securing anew the conditions, forces, and relations of production, expanding the scale and scope of commodification and capital accumulation, and offset-

220 ting crisis tendencies, all with the potential to undermine both value embodied in existing landscapes as well as the legitimacy of existing political arrangements and institutions. Such processes could operate at various scales (including the urban-regional, national, and global) and also within and across different sectors (e.g., the Green Revolution has largely been a sectoral but international fix, whereas the New Deal was far more general in scope, but more limited to the United States) with the specific configurations being a question of contingency. Although fixed capital represents in significant measure the material content of any fix, it also embodies and conveys various representations and ideologies that might help secure the legitimacy of particular social classes and coalitions, along with institutions and political conditions. Unpacking the specifically socioecological character and functioning of fixed capital within this broad framing is our focus.

Harvey (1982) explained that "when the various instruments of labour are produced as commodities, exchanged as commodities, productively consumed within a work process given over to surplus value production and, at the end of their useful life, replaced by new commodities, they become, in Marx's lexicon, fixed capital" (205). Importantly, these types of capital are utilized over a number of production cycles. At first blush, this definition of fixed capital seems far removed from the question of nature and a socioecological fix, but both Harvey and Marx in turn are quite expansive in their notions of the means of labor. The conditions of production and distribution in general, including anything from soil to railways, and the various parts of the built environment (broadly understood) operate as fixed capital insofar as they pass value on to commodities over multiple production cycles and facilitate circulation and accumulation. In his Companion to Marx's Capital Volume 2, Harvey (2013) wrotes, "when we go beyond the image of fixed capital as mere machine, we find ourselves conjuring up a picture of capital building whole landscapes of cleared fields and factories; of highways and railways, or ports, harbors and airports; of dams, power stations and electric grids; of gleaming cities and massive industrial capacity" (111).

For both Marx and Harvey, one of the key instigators of fixed capital formation is the threat or realization of capitalist crisis. Marx ([1885] 1978) wrote in Volume 2, "catastrophes, crises, etc. are the principal causes that compel such premature renewals of equipment on a broad social scale" (250). Marx was very clear that fixed capital formation requires overabundance and he suggested that this emerges from transformations of productive forces and the historical movement from private labor to social labor. Marx ([1858] 1973) wrote, "Surplus population ... as well as 
surplus production, is a condition for [fixed capital formation]" (707), and suggested that as the scale of infrastructure projects grow, so, too, must the size of the surpluses or the pot of fictitious capital generated

280 through credit and financial mechanisms with the latter increasingly representing the terrain on which fixes might be unfolding (see Johnson 2015). In this respect, the possibility of a fix is largely immanent to, albeit not determined by, crises of overaccumulation and 285 their associated surpluses.

As Glassman (2007) suggested, the question of what can and should be done with surpluses in the establishment of recovery programs is the product of political and social struggles rather than solely a reflection of

290 determinative economic processes. As informed by particular coalitions of social interests and institutions, moreover, a particular fix might serve to direct fixed capital formation at addressing socioecological contradictions associated with particular trajectories of accu-

295 mulation. Surpluses, in turn, become embodied in the physical landscapes or as processes and machinery that act as conditions, forces, and conduits for renewed accumulation and circulation as well as for social life more generally. This is precisely why fixed capital is so

300 important for any account of a fix-because, as Harvey suggested, fixes must either displace or absorb surpluses to restore and enhance the conditions, forces, and relations of production also in material conditions for social reproduction. Moreover, the role of

305 politics in crisis formation means that the state, as a crystallization of broader social forces, is pivotal in shaping recovery plans and capital switching, not least in its capacity to finance investments directly and through the provision of credit. But what precisely is 310 sunk into, or embodied within fixed capital?

When we historicize fixed capital-or, in other words, when we investigate the specific and contingent formation of fixed capital and the processes, materials, ideologies, and forms of knowledge that

315 become congealed in actual landscapes and infrastructure-it becomes apparent that these forms of capital can be understood as produced forms of socionatures. Marx ([1858] 1973), in fact, pointed to the socioecological character of fixed capital: "The reproduction of

320 fixed capital requires ... that a part of living labour and of raw materials be used to produce instruments of production, direct or indirect ones, instead of producing exchangeable products" (735). If fixed capital formation in response to a crisis or threat of a crisis is the

325 foundation of a socioecological fix, then it becomes important to account for both the labor and raw material (specific socionatures) out of which any fix is constituted: In short, it is important to understand the metabolism of fixed capital as an essential feature of the function of fixed capital as such.

Starting with labor, Marx ([1858] 1973) explained that "In fixed capital, the social productivity of labour [is] posited as a property inherent in capital; including the scientific power as well as the combination of social powers within the production process, and finally, the skill transposed from direct labour into the machine, into the dead productive force" (715, italics in original). Marx was suggesting here that the increasing productivity of labor, which is often reified as a trait of fixed capital itself, is in fact an accumulation of social labor and forces. Harvey (1982) added that fixed capital "ensures the domination of past 'dead' labour (embodied labour) over living labour in the work process" (237). This claim has been at the heart of D. Mitchell's (2003; see also D. Mitchell 1996, 2000) work, in which he argued, "the landscape can be understood to be a product of human labour, of people going to work on the land to make something out of it" (238).

The building of social forces into landscapes requires not simply the deployment of physical labor in a narrow sense, however, but also various sorts of scientific and ideological inputs (also forms of labor) that contribute to the substance and meaning of fixed capital, a theme to which we return. At one point, Marx ([1858] 1973) wrote: "Nature builds no 355 machines, no locomotives, railways, electric telegraphs, self-acting mules etc. These are products of human industry; natural material transformed into organs of the human will over nature, or of human participation in nature. They are organs of the human brain, created by the human hand; the power of knowledge, objectified" (606). ${ }^{2}$ This point might seem painfully obvious, if not banal, if one considers the engineering science that becomes objectified in fixed capital (e.g., consider biotechnology; see Kloppenburg 1988; Prudham 2003), but it signals the need to recognize the diverse types of activities and scientific labor that contribute to fixed capital formation. Recognizing this point means engaging with the specifically metabolic character of fixed capital formation, a specifically socioecological process involving social labor (as "dead" or past labor) becoming embodied in physical forms through the transformation of various biophysical materials and processes into conditions of production. Marx ([1885] 1978) suggested, "all capital that 375 functions as productive capital is fixed in the production process, and thus so are all the elements of that 
productive capital, whatever may be their material shape, their function, or the mode of circulation of 380 value" (242).

Huber (2013) followed Marx's argumentation, suggesting that the material resources that comprise fixed capital and machinery represent the amassing of what he called "dead ecologies." His focus is on fossil fuels

385 that have been and remain essential to the establishment and functioning of a vast technological and infrastructural apparatus tied to those fuels, particularly in their guise as energy sources. Huber's language, although a playful riff on Marx, perhaps underplays

390 the lively or generative capacities of these material instruments of production and energy, as is demonstrated by his own work. It might be more accurate, then, to suggest that the raw materials and energy that power fixed capital are lively ecologies that always

395 exist in relation to the deployment of social labor (dead and living) and the circulation of value; they are thus internal relations in the production process. The work of Marx, and much more recently, Huber, suggests more generally, as we claim, that any and all

400 fixed capital might be understood as produced forms of nature.

The socioecological character of fixed capital becomes even more apparent when we consider Marx's reflections on investments in landscapes and processes

405 nominally and normatively understood as "natural," namely agriculture, forests, and waterworks. For instance, Marx ([1885] 1978) discussed the rootedness of fixed capital investments: "products that have been localized by being incorporated into the earth, and

410 hence can only be used locally, e.g. factory buildings, railways, bridges, tunnels, docks, etc., soil improvements, and so on, cannot be exported body and soul" (288, italics added). At another point Marx ([1885] 1978) suggested, "the circumstance that some means

415 of labour are fixed in location, with their roots in the soil, gives this part of fixed capital a particular role in a nation's economy"(242, italics added; see also 289).

The language Marx used signals the material basisthe "earthliness" of which Gramsci wrote-of fixed

420 capital and hence the socioecological character of the infrastructure that comprises any fix, as well as the diversity of relations and processes implicated. Marx certainly did not anticipate the multitude of ways that social labor and capital would circulate within, and

425 transform biophysical natures (how could he?), nor could he fully anticipate the development of ecology as a domain of knowledge emphasizing the interconnectedness of life and the conditions for it. Still, his choice of examples of fixed capital investment in Volume 2 and the Grundrisse are highly suggestive that he was interested in biophysical processes as embodiments of fixed capital while also attending to the complex relation between concrete and abstract forms.

Debates on the production of nature that we highlighted in our first article insist that labor is key to the metabolic process that binds together humans and nonhumans in a dynamic, coconstitutive relationship (Swyngedouw 2006; Smith [1984] 2008; Eaton 2011; Ekers and Loftus 2013b). In a much-quoted passage Marx ([1867] 1977) argued: "[The labour process] is the universal condition for the metabolic interaction between man [sic] and nature, the ever-lasting nature imposed condition of human existence, and it is therefore independent of every form of that existence, or rather it is common to all forms of society in which human beings live" (283, 290; cf. Marx [1858] 1973, 87). Swyngedouw $(2006,108)$ argued that in the hands of Marx and Engels, metabolism literally refers to "change of matter" ("stoffwechsel"), a point he leveraged to suggest that as matter changes, new natures are produced. Yet it should be added that this process takes place in concert with the operation of fixed capital, which itself is a product of labor. At several points, Marx ([1867] 1977, 548, 614) suggested that labor becomes a "living appendage of a machine" (a phrase that in itself highlights the socioecological character of fixed capital and labor in so much as living labor is inherently socioecological or sociotechnical). Although this specific reference is to the real subsumption of labor, Marx's work suggests that social labor, fixed capital, and specific socionatures are truly fused together as metabolic unities in the production process.

Since fixed capital, in the sense of a produced production force, as agent of production, increases the mass of use values created in a given time, it cannot grow without the raw material it works on also growing (in manufacturing industry. In the extractive industries, such as [a wild] fishery, mining, labour merely consists in overpowering the obstacles in the way of the seizure and appropriation of the raw products or primary products. There is no raw material to be worked up for production; rather, the existing raw product is appropriated. By contrast, in agriculture the raw material is the earth itself; seed the circulating capital etc.). Its employment on a larger scale thus presupposes expansion of the part of circulating capital consisting of raw materials; hence growth of capital generally. It likewise presupposes (relative) decrease of the portion of capital exchanged for living labour. (Marx [1858] 1973, 715) 
480 In this passage, although problematically reifying certain types of socionatures as impediments to the development of productive forces, Marx nevertheless signaled that fixed capital, as "a produced production force" (or produced form of nature), necessitates an

485 accelerated and expanded metabolism of various "raw materials." Fixed capital formation, understood as the physical congealment of accumulated ecologies and historical-geographical labor processes, goes hand in hand with the expansion, intensification, and transfor-

490 mation of material processes of resource flow and waste production, essential features of understanding capitalism as an "ecological regime" (the phrase is that of Moore 2011, although we suggest "regimes" in the plural is more apt).

495 The preceding passage from Marx also highlights how both intensive and extensive processes are internal to any fix. Investments in ecological landscapes and processes represent an in situ effort to turn "nature" into a "produced production force" yet are

500 connected to wider metabolic and circulatory transformations. One example would be landscapes flattened, turned over, and carefully irrigated to foster intensive agricultural production and the easy use of machinery (D. Mitchell 1996, 2003; Henderson 1999; Walker

505 2004). The adoption of intensified forms of agriculture require inputs, including, for instance, improved (and more recently genetically modified) seed, water for irrigation, energy, fertilizer and pesticide inputs, and so on. These flows in turn are supported by extensive 510 socioecological geographies that might include massive watershed transformations, extensive networks of energy supply, production, and distribution, and large-scale movements of people (see Walker 2004; see also Swyngedouw 2000). The history of the

515 Green Revolution is nothing if not the relational fusion of intensive and extensive moments, facilitating more capital-intensive agriculture in place while also extending and integrating global agriculture into a productivist regime (Weiss 2007; Clapp 2012; Patel

520 2013). Almost any intensive fix then is necessarily underpinned and made possible by extensive political economic and metabolic processes.

\section{Fixed Capital, Value, and the Subsumption of Nature}

525 Given the preceding, can we conceptualize fixed capital formation as a metabolic process involving the production of nature in relation to what has been termed the "subsumption of nature"? Harvey (1982) explained in general terms that "fixed capital is not a thing but a process of the circulation of capital through the use of material objects, such as machines" (205). We can thus consider the ways that accumulated socioecologies, as forms of dead labor embodied in fixed capital, help to drive (or impede) the production and flow of value through physical infrastructure and landscapes of production.

Yet, diverting capital by fixing it within landscapes and socioecological processes is not without tension. As Marx ([1858] 1973) suggested, fixed capital is distinguished from other forms of capital because of its use (value): "[Materials] are fixed capital not because of the specific mode of their being, but rather because of their use. They become fixed capital as soon as they step in the production process. They are fixed capital, as soon as they are posited as moments of the production process of capital; because they then lose their property of being potentially circulating capital" (681, italics in original; see also Marx [1885] 1978, 240, 288-89). Harvey built from this and related insights, arguing that fixed capital is unique insofar as it is not physically reproduced or manifest in the products of production, yet is still defined by the flow of value, embodying a dynamic tension between fixity and motion. The value internal to fixed capital is thus passed on to commodities relatively more slowly, through repeated production processes, making the turnover time of physical infrastructure and machines necessarily slow in comparison to other commodities.

Among other implications, this means that fixed capital and any associated fix involving capital switching comes with a distinct temporal dynamic. Part of the total amount of circulating capital must be removed from circulation to create various forms of fixed capital and might only return to circulation over the course of years or decades, if ever, dependent on the stability of the social forces and institutions supporting a fix. At the same time, this fixed portion of the total social capital, imprisoned in particular landscapes and socioecological processes with its longer turnover time, in turn shortens or lowers the turnover time of commodity capital in circulation, also qualitatively altering the relations of production, distribution, and consumption. This dynamic (and dynamic tension) captures two connotations of Harvey's notion of fix, one being a solution for the problem of surplus capital, the other being the formation of definite spatial and socioecological conditions that facilitate and accelerate capital circulation. 
In this way, we can also see that the metabolic 580 transformation of specific socionatures within socioecological fixes is linked to the production of surplus value. As Harvey (1982) explained, the built environment "functions as a vast, humanly created resource system, comprising use values embedded in the

585 physical landscape, which can be utilized for production, exchange and consumption. From the standpoint of production, these use values can be considered as both general precondition for and direct forces of production" (223). Fixed capital, in general, lowers

590 the socially necessary labor time embodied in a commodity as well as the turnover time of capital. Both Marx and Harvey were clear in arguing that capitalist value is recognized only as it is produced by living labor, not machinery or infrastructure as such, even

595 though these latter embody the past exertions of living labor. Equally, however, fixed capital is essential to the indirect production of value through the determination of the conditions under which value is produced, and specifically, to the determination of the

600 average socially necessary labor time required to produce a given commodity.

Moreover, as Marx also argued, the historical development of the stock of fixed capital in relation to the mass of living social labor deployed in production is an

605 essential dimension of the distinction between the formal and the real subsumption of labor as contrasting logics of production and valorization. ${ }^{3}$ This distinction, in turn, has far-reaching consequences in terms of the relative autonomy of labor within the produc-

610 tion process, as well as the form that the extraction of surplus value (specifically, absolute vs. relative) takes. As Smith (2007) summarized, "The formal subsumption of labour took place when workers entered a wage relationship with capital but still maintained some

615 immediate, creative control over the daily labour process. The real subsumption of labour to capital occurred when workers became cogs in the machinery of modern industry. ... Not only were they subsumed as a result of the direct wage relation; they were now

620 subsumed within the multidimensional web of capitalist technology and social organization" (28, italics added). ${ }^{4}$ At one level, then, the metabolism of socioecological fixes ties the production of nature in the form of fixed capital to the transformation of the labor process and 625 the tendency toward the real subsumption of labor.

Further, the metabolism of the built environment also could be said to involve conjoined and contrasting logics of the formal and real subsumption of nature (Boyd, Prudham, and Schurman 2001; Smith 2007;
Ekers 2015). Smith (2007) explained that "with the formal subsumption of nature, capital accumulation is facilitated predominantly by a continual expansion in the conversion of extracted material into objects of production" (28-29). Smith continued, suggesting "while capital has always circulated through nature ... the real subsumption of nature not only intensifies this circulation but transforms it from an incidental effect of capital accumulation to an intended strategy" (29). Although Smith did not make this point, we argue that the formation of fixed capital and infrastructure is integral to the process of the real subsumption of nature, a point that Marx ([1858] 1973) cames close to making directly in the Grundrisse:

In one respect the transformation of the production process from the simple labour process into a scientific process, which subjugates the forces of nature and compels them to work in the service of human needs, appears as a quality of fixed capital in contrast to living labour; while individual labour as such has ceased to appear as productive, is productive, rather, only in these common labours which subordinate the forces of nature to themselves. (700, italics added)

Marx ([1858] 1973, 733; [1885] 1978, 239-40) repeatedly singled out the uniqueness of agriculture, other biological processes, and infrastructure as sinks for capital: Soil and agriculture, water and irrigation works, and trees and plantations receive special attention in his writing. He wrote, "The progressive reinvestment of the money reserve fund (i.e. of the part of the fixed capital that is turned back into money) is most easily effected in agriculture. Here a spatially given field of production is capable of the greatest gradual absorption of capital" (Marx [1885] 1978, 252). Marx thus signaled how investments in landscapes and ecological processes can act as sinks for capital (a crucial part of any fix as discussed earlier). The sinking of capital can alter its circulation through "nature," changing the productive character of socioecological processes and infrastructure. As Marx ([1858] 1973) explained, "no longer does the worker insert a modified natural thing [Naturgegenstand] as middle link between the object [Objekt] and himself; rather, he inserts the process of nature, transformed into an industrial process, as a means between himself and inorganic nature, mastering it" (705). The investments in "the process of nature" accomplished through a socioecological fix represent an intervention in the conditions and forces of production. Long-term investments into reforestation that include various strategies 
680 to take hold of and augment the growth of forest trees (including so-called tree improvement) comprise one of the more textbook examples of such fixes (Prudham 2003, 2005; Ekers 2009, 2015). In turn, these investments are part of the more general process of trans-

685 forming the subsumption of labor along with the means by which surplus value is produced; that is, they deepen the production of relative versus absolute surplus value.

\section{“Nature's Difference”: On Use Values}

690 Within a framework relating the metabolism of fixed capital formation to the formal and real subsumption of labor, how do we grapple with and retain the specificity of socioecological processes as internal relations? As we discussed in the first of our articles,

695 the treatment of "use-values" and the materiality of nature is underdeveloped within some Marxist approaches to the production of nature, as has been flagged by a number of critics (Braun 2002, 2006; Bakker and Bridge 2006). An adequate account of a

700 socioecological fix, however, needs to account for the historical-geographical difference that "nature" makes in the context of fixed capital formation. As we discuss in this section, Marx himself is rather ambivalent on this point, yet his writings are at the same time highly

705 suggestive, indicating how the particularities of socioecological processes and landscapes shape the formation, circulation, and realization of capital (and vice versa).

Throughout Marx's writings, there are claims that

710 would seem to make the specific "natural" features of use-values irrelevant to capitalist accumulation; yet there are also numerous instances where he attended to the difference that specific biophysical processes or natures make in commodification, the circulation of

715 capital, and the formation of fixed capital. In the Grundrisse, Marx ([1858] 1973) wrote:

The crude materialism of the economists who regard as the natural properties of things what are social relations of production among people, and qualities which things obtain because they are subsumed under these relations, is at the same time just as crude an idealism, even fetishism, since it imputes social relations to things as inherent characteristics, and thus mystifies them. (687, emphasis added; on this specific point, see also Sayer 1987)

725 Both Harvey and Marx highlighted not only the limits of idealism in general terms and as is well known, but also (as is less well recognized), the risks of a naive materialism. This dual threat is most clearly expressed in Marx's ([1845] 1998) Thesis on Feuerbach (on this point and the limits of a crude or naive materialism specifically within Marxist political ecology, see Loftus 2009b; Mann 2009). Yet, as we flagged in the first article, there is a genuine risk of understating the significance of the diversity of socionatural "usevalues" if, using Smith's framework, first nature is seen as produced from within and dominated by second nature. This, we have argued, is one of the limits of Smith's production of nature thesis as he developed it. At play within Marx's writings, however, is the basis of a more nuanced appreciation of the influence of diverse socionatural materialities (as historical or received contingencies) on the circulation of capital through the built environment and production processes. When commenting on the reproduction of capital "as raw material, as product, and as means of 745 production," for instance, Marx ([1858] 1973) wrote:

In purely extractive industries, e.g. mining, the mine itself exists as the material of labour, but not as raw material passing over into the product, which latter must, in the manufacturing industry, by contrast, have a particular existence in all forms. In agriculture, seed, fertilizer, cattle etc., may be regarded as raw material as well as matières instrumentales. Agriculture forms a mode of production sui generis, because the organic process involved, in addition to the mechanical and chemical process, and the natural reproduction process is merely controlled and guided; extractive industry (mining the most important) is likewise sui generis, because no reproduction process whatsoever takes place in it, at least not under our control or known to us. (726, italics in original)

This passage is perhaps one of Marx's clearest indications that he considered the diverse materialities of socionatures significant to and even constitutive of the very logic by which capital circulates. He posited a specific distinction between agriculture and mining that turns on whether a "reproduction process" takes place that can be guided, controlled, or intensified at any particular historical-geographical conjuncture. In Volume 2 of Capital, Marx ([1885] 1978) wrote, "In so far as this time of production over and above the labour time is not determined by natural laws given once and for all, as with the ripening of corn, the growth of an oak, etc., the turnover period can often be shortened by the artificial shortening of production time" (317).

Building on this point, Boyd, Prudham, and Schurman (2001) argued that in the case of nonbiological resources, capital is generally restricted to the formal 
subsumption of nature because "firms confront the bio-

780 physical world as an exogenous set of stocks or flows, biophysical processes, and material characteristics" (562). In contrast, the capitalization of biological socionatures might involve a process more akin to real subsumption, in which "capital circulates through

785 nature (albeit unevenly) as opposed to around it. Biological systems are made to act as actual forces of production" (Boyd, Prudham, and Schurman 2001, 565 , italics in original).

This distinction is not without its critics. Smith 790 (2007), in fact, rejected a one-to-one mapping of the formal and real subsumption of nature onto nonbiological and biological entities and processes respectively. Instead, he argued that the transformation of the logic of subsumption vis-à-vis the pro-

795 duction of nature turns on the degree to which socionatures become targets for the intensification of capital accumulation, also arguing that this comes with the consequence that capital accumulation becomes more and more conjoined with the

800 circulation of nonhuman natures (in his words, "the circulation of nature through capital, is ... transformed from an incidental to a strategic process" [Smith 2007, 29]). We are sympathetic to his point even as we feel it is important, at least historically,

805 to recognize the distinct and distinctly significant ways that biological processes have actually been targeted and intensified as accumulation strategies, not least in the age of commercial biotechnology.

Our more general emphasis here, though, drawing

810 from Marx's observations about mining and agriculture, is on the specific ways that historically received biophysical processes constitute the trajectory and logic of particular socioecological fixes, and on the manner in which produced socionatures of particular

815 kinds contain and surrender value over time. In the case of what Marx described as organic natures, a fix might take place through sinking capital into the material fabric of the processes under consideration (e.g., trees, agricultural processes, biotechnology) in

820 an attempt to decrease the turnover time of capital. In contrast, with abiotic elements (e.g., oil and minerals), a fix might be focused on long-term fixed capital projects that bring online new resource supplies, on projects that enhance extraction processes, or on

825 communication and transportation network improvements that decrease turnover time. A fix might entail all of these. How all this works is a matter of historical materialism, not in theory, but in practice. We can't divine the form and content of a socioecological fix from the material entities and processes under consideration. Rather, they comprise part of complex but unified metabolisms. As Henderson (1998) suggested, capital's relation to nature is tied to how "nature repels and attracts capital in different ways according to the historically contingent tendencies of circulating capital" (76). Building on this point, a socioecological fix is always going to be a response to the historical and geographical contingencies of socionatures and how these then become mobilized within a broader conjuncture.

Yet it also bears noting that socioecological fixes might not and sometimes do not succeed on their own terms, whether accelerating the turnover time of commodity capital, or in terms of providing relief to crisis tendencies. Capital accumulation is, it is important to remember, an inherently speculative undertaking. To use an example we have invoked in both of our articles, large-scale investments in reforestation might fail to generate profitable returns if new resource frontiers with lower production and labor costs undermine them. In addition, projects such as the various pipelines proposed to move surplus oil from Canada's Alberta tar sands to coastal markets in British Columbia, eastern Canada, or the southern United States might fail to materialize because of social opposition from a combination of First Nations and environmental groups that thus far have proven quite effective. Such social struggles, when combined with low oil prices, might have the effect of seriously eroding the viability of the tar sands as a socioecological fix for the oil and gas sector (Zalik 2015). Finally, there is the possibility that the specific materiality of types of fixed capital might prove to be an impediment to accumulation. T. Mitchell's (2002) discussion of the Aswan Dam in The Rule of Experts is a key example where the specificities of the land troubled the dam's construction, compounding a litany of contingent aftereffects and highlighting the difficulties inherent to large-scale infrastructure development en a landscape scale.

To summarize, we have argued that fixed capital created in response to crisis is inherently socioecological and can be understood as a produced form of nature. Our attention has been on how fixed capital established as a part of a socioecological fix might help secure the conditions and forces of production necessary for facilitating the accumulation of capital, but equally, the unevenness of these possibilities as conditioned by the specific materialities of socionatures. We now turn to a discussion of how the formation of fixed capital intervenes in the broadly understood relations 
Ekers and Prudham

of production, and more specifically, the politics and rhythms of hegemony and everyday life.

\section{The Fix and the Pursuit of Hegemony}

Thus far we have presented a fairly austere account 885 of socioecological fixes, emphasizing the formally economic and physical moments of fixed capital formation in response to crises. In this final section, we expand the framework we have thus far developed to consider more broadly how socioecological fixes artic-

890 ulate with and are shaped by struggles over hegemony and the broader rhythms of everyday life via the cultural politics surrounding the production of space and nature.

Harvey (2013) in his Companion to Marx's Capital,

895 Volume 2, suggested, "the general framework Marx sets out constitutes a straitjacket that limits the applicability of these laws [of accumulation] and leaves us a lot of work to do to understand particular historical movements and conjunctures" (16). This, remark can per-

900 haps be read as a candid moment of self-critique within his writings and could also be aimed at what we have offered so far.

Our point of departure for understanding a broader or more-than-economic set of relations at play within

905 any fix is Gramsci's understanding of crisis, a perspective better developed in political and cultural terms than what we find in most writing concerning crisis tendencies, including specifically socioecological ones. Harvey, as we suggested in our first article, focuses on

910 the tension between the forces and relations of production but not in terms that involve socioecological entities, processes, and relationships. Moore (2015) took ecological crises more seriously but, writing on the current conjuncture, suggested, "in place of the converg-

915 ing crises model, we may instead view our era's turbulence as a singular crisis - of capitalism as a way of organizing nature-with manifold expressions" (298). He added, "[f]lood and climate, finance and energy represent not multiple, but manifold, forms of crisis ema-

920 nating from a singular civilization project: the law of value as a law of Cheap Nature" (298).

Harvey's emphasis on the relations and forces of production and Moore's claim to a "singular crisis" and a "singular civilization" can be with 925 Gramsci's (1995) of crisis, offered in relation to the depression of the 1930s:

Special consideration must be devoted to a study of the events which may be subsumed under the name of crisis and which have been prolonged catastrophically from 1929 right down to today. Whoever wants to give one sole definition of these events, or, what is the same thing, find a single cause or origin, must be rebutted. We are dealing with a process that shows itself in many ways, and in which causes and effects become intertwined and mutually entangled. To simplify means to misrepresent and falsify. Thus, a complex process, as in many other phenomena, and not a unique "fact" repeated in various forms through a cause having one single origin. (219)

Gramsci warned against boiling a crisis down to a single definition, cause, or point of origin. He signaled that "causes and effects become intertwined and mutually entangled," and his writings emphasize that formally "economic" relations are always articulated with the formally noneconomic (i.e., political, social, and cultural) relations (Hall, Lumley, and McLennan 1977; Buttigieg 1990; Thomas 2009; see also Glassman 2003). Others have suggested that socioecological relations need also to be included (e.g., Mann 2009; Ekers and Loftus 2013a; Karriem 2013). If socioecological fixes are responses to crises, then how we understand these crises must inform how we theorize the fixes that emerge in response, a point also made by Glassman (2007).

Following Gramsci, we must recognize the broad, multidimensional character of crises and fixes and the thoroughly cultural and political moments (understood as internal relations) of attempts to displace crises through fixed capital and infrastructure projects. The question of hegemony and legitimacy is not reducible to capitalism as a mode of production, but we suggest that capitalism does create repeated socioecological legitimacy crises that can be addressed through particular fixes (see Ekers 2009). Building on these points, and as we discuss later, engaging with Gramsci pushes us to consider how a socioecological 965 fix doubles as a hegemonic project, or so we argue. The problem is that despite Gramsci's insightful writings on "nature" (see Fontana 1996; Loftus 2013; Wainwright 2013), he had little to say about the relationships among environmental change, environmen- 970 tal politics, crisis, and political legitimacy per se.

As in our first article, we find O'Connor's (1997) singular work helpful in this regard. O'Connor certainly suggested that the growth imperative of capitalist accumulation contradicts and undermines the reproduction of localized "natural elements" that are metabolized in production processes. His argument in this respect broadly coheres with "eco-Marxist" understandings of capitalist dynamics of environmental
930 
980 change (for which, we should note, O'Connor's work has also come under trenchant critique for its alleged determinism and reification of an external nature; see Castree 1995, 2000, 2001, 2002; Harvey 1996; Henderson 2009). Yet these critiques miss one crucial 985 dimension of O'Connor's argument. In his words, "given the politicization of the conditions of production, if these conditions are neglected, and/or their productive powers damaged, there arises the possibility not only of an economic crisis for capital but also of a legitimation crisis for the state or a political crisis for the ruling parties and government" (italics added). On this latter point, certain resonances with Gramsci exist (even if their respective styles of Marxism diverge widely in a more general sense). For us, this conver-

995 gence points to the need to expand our understanding of the character of fixed capital, and in particular, its "more-than-economic" character along the lines we describe next.

\section{Fixed Capital, Nature, and Hegemony}

1000 Fixed capital, as we discussed in the last section, can be understood in Marx's language as a "produced production force," or in Smith's terms as a particular production of nature. The formation of fixed capital can be discussed narrowly; that is, as a formally economic

1005 and strictly "materialist" phenomenon. It is also possible, however, to advance a broader formulation in which fixed capital is situated within and constituted by a wider social canvas and as embodying and expressing cultural and political meaning. Exploring

1010 the significance of fixed capital through an expanded theoretical lens highlights for us the representational and ideological dimensions of spatial and socioecological fixes, dimensions that have received very little attention outside of Gilmore's (2007) nuanced

1015 account of the militaristic and racist ideologies embodied in the "prison fix" in California. Recognizing ideological and representational dynamics as internal to a fix is pivotal for understanding how hegemony, as the maintenance and legitimation of power and particular social relations, is tied to the fixing of socioecological processes. We find Gramsci extremely helpful in this respect.

Gramsci's relational Marxism was rather unique at the time of his writing. In many respects, he was react-

1025 ing to currents of economic reductionism and teleological readings of history and politics that were prevalent in socialist and communist circles in his day. In response, and as a critique, Gramsci developed a much more relational and historicist approach to historical materialism, central, for instance, in understanding his aforementioned comments on crises. That said, within his work there is no meticulous formal, deductive, and abstract working through of the dynamics of capital accumulation such as what is found in Harvey's writing. This is precisely why it is useful to draw on both writers. What Gramsci did offer was an incredibly detailed analysis of the interweaving of political, economic, and cultural relations in the establishment of bourgeois and fascist hegemony and the broad tactics, alliances, and worldviews that oppositional forces would need to adopt in a successful countermovement (Hall, Lumley, and McLennan 1977; Thomas 2009; Santucci, Di Mauro, and Engel-Di Mauro 2010; Wainwright 2013).

The concept of hegemony grounded and guided Gramsci's intellectual and political project. Hegemony, for Gramsci, referred to the reinforcement and reproduction of power relations, authority, and legitimacy through processes of reification (of particular modes of production, class and other social formations, ways of life, institutions, practices, etc.) whereby prevailing norms take on the guise of "common sense" (Buttigieg 1992; Thomas 2009; Santucci, Di Mauro, and Engel-Di Mauro 2010). The achievement of hegemony was closely bound to the uptake of the ideas and interests of elite social classes by society more generally, including across both civil society and the state, which together Gramsci understood as the "integral state" (Jessop 1990; Morton 2007; Thomas 2009). Via these means, hegemonic social blocs express their interests as the interests of society as a whole.

To our knowledge, no explicit discussions exist of how a spatial fix might double as a hegemonic project. Glassman (2007) came the closest in discussing how "there is always room within processes of social and political struggle [over crises and fixes] for the formation of political alliances and/or hegemonic blocs" (352). Similarly, D. Mitchell (2000) wrote, "like culture ... the landscape acts as a site of social integration, and therefore of social hegemony" (141). We concur with Glassman and Mitchell, but Gramsci did not discuss fixed capital as such. That said, he did address how the planning and construction of urban spaces (streets, street names, architecture, etc.) constitute the experiences of everyday life and thus comprise part of the fabric of hegemony (see Kipfer 2008; Loftus 2009a, 2012). From these and related insights, and drawing on the aligned work of others who have drawn from Gramsci, it is possible to more explicitly 
1080 interrogate the articulation of fixed capital formation with questions of legitimacy and hegemony.

In general terms, for our purposes, it is important to consider how the production of nature, as a produced production force, is also an inherently cultural and 1085 political process. In a retrospective piece, Smith (1998) himself both clarified and extended his original thesis, arguing that "production should not be restricted to those acts of manual and not imaginative work, economic and not cultural creation, individual

1090 labour rather than social accomplishment, and the making of objects rather than the productive consumption by subjects" (277). Smith highlighted here a more nuanced understanding of the production of nature than his critics often recognize. Building on

1095 these sentiments, fixed capital, as a form of produced nature, needs to be understood not only as a consolidation of physical "stuff" nor strictly in terms of its economic function, but also as a cultural creation that intervenes in the domain of meaning. This includes

1100 shaping the ideological and representational relations and currents that animate socioecological entities and relationships, even as the apparent stability or "naturalness" of landscapes acts ideologically to disguise processes of historical change and political con-

1105 testation (see Wilson 1992; D. Mitchell 1996, 2000; Gandy 2002; Walker 2004).

There are, of course, numerous precedents for such a line of argumentation. ${ }^{6}$ One of the most compelling aspects of recent studies of political ecology is the

1110 attention placed on the representational and symbolic character of infrastucture. Building on the work of Smith (2008), Lefebvre (1991) and Buck-Morss (1995), a number of commentators have examined how the development of urban infrastructure entails a

1115 particular mixing of social and ecological processes, at the same time representing much more than simply bricks and mortar (see, e.g., Heynen, Kaika, and Swyngedouw 2006). In this register, urban form and urban networks reflect and reinforce prevailing social

1120 relations, power dynamics, and ways of understanding and living in the world (Kaika and Swyngedouw 2000). Infrastructure in the form of dams and waterworks, electricity works, and parkways act similarly. Fixed capital, from this perspective, plays a vital role 1125 not only in facilitating economic function, but also in helping to secure the legitimacy of particular social orderings and the consolidation of specific socioecological relations and registers of meaning.

At a concrete level, for example, Kaika's (2005) 1130 work demonstrates how megadams and other forms of water infrastructure have functioned historically as "wish-images, objects of delight and desire in themselves, signs of a better society that was yet to arrive" (39). She added, "in their fetish role, networks and their nodal infrastructures were not just carrying water, electricity, etc. into the city, but [they] also embodied the promise and the dream of a good society" (Kaika 2005, 40). Swyngedouw's (1999, 2007, 2015) integrative historical geographies of Spain also pay careful attention to how consent to fascist rule was orchestrated through reworking regional and national hydrosocial landscapes that were deeply physical and symbolic. Finally, Graham and Marvin (2001), writing about the "integrated infrastructure ideal," suggested that "infrastructure networks and the sociotechnical processes that surround them, are strongly involved in structuring and delineating the experiences of urban culture and what Raymond Williams (1973) terms the 'structures of feeling' of modern urban life" (12).

The central contribution of this literature to an understanding of socioecological fixes lies in the explorations of the simultaneity of material and symbolic dimensions of spatial and socioecological changes, largely in an urban context. This is always in concert, however, with an emphasis on questions of political legitimacy, including the ideological dimensions of historical geographical landscape change. These themes echo Gramsci strongly even where he is not explicitly invoked. For Gramsci, the achievement and maintenance of hegemony is, in part, secured through the dense imbrication of civil society and the state. Gramsci (1971) wrote, "In the West, there was a proper relation between State and civil society, and when the State trembled, a sturdy structure of civil society was at once revealed. The State was only an outer ditch, behind which there stood a powerful system of fortresses and earthworks" (238). Gramsci's point here is that the maintenance of hegemony is achieved through a dense network of civil society organizations that support the state. Our argument is that the political economic and cultural dimensions of fixed capital and infrastructure as forms of produced nature comprise conjoined parts of the "fortresses and earthworks" that support particular forms of power and rule, in part via their appeal to broad cross-sections of society.

Within this, it is important to note Gramsci's particular contributions to understanding how ideology operates, and specifically, his advancement of a materialist conception of ideology (Hall, Lumley, and McLennan 1977; Thomas 2009; Santucci, Di Mauro,
1135 
and Engel-Di Mauro 2010; Rehmann 2014). Gramsci deployed several notions of ideology, but the materialism of his understanding, in part, is based on his appre-

1185 ciation of the ways that ideologies are expressed physically within landscapes and institutions, via "fortresses and earthworks" to repeat his memorable (and apt) phrase. As Rehmann (2014) wrote, "it was mainly Gramsci's fundamental opposition to econo-

$1190 \mathrm{mism}$ and class-reductionism that enabled him to understand the ideological not in terms of mere ideas, but rather as a material ensemble of hegemonic apparatuses in civil society" (124). In other words, "wish images," an "integrated infrastructure ideal," support

1195 for fascist rule, are only possible because ideologies of "progress," "modernity," and nationalism take on a physical form and become expressed in fixed capital and infrastructure, the dams and waterworks constructed throughout Spain during Franco's rule being a

1200 case in point. D. Mitchell (2000) captured such a position when writing about landscape, noting, "as social values are naturalized in place, they are historically made concrete" (142, emphasis in original).

The other key element to Gramsci's understanding

1205 of ideology is its performative character. For Gramsci, ideology actively organizes and constitutes social life. The meanings and symbols embodied in fixed capital may become assumed, lived, and felt, but they are also contested in the practices of everyday life. Ideologies

1210 and hegemonic relations must be lived to be reproduced. From this perspective, there is no guarantee that the messages and representations embodied in any socioecological fix will be successfully translated into social action and life in the ways intended, or

1215 that existing power structures, social relations, and institutions will be bolstered by the projects with which they become associated. As D. Mitchell's (1996, 2000) work suggests, the process of landscape change is the product and cause of social struggle. Just

1220 as a fix might fail as a response to crisis based on its physical makeup or because of shifting political economic relations, struggles, and coalitions, a fix might fail as a "meaning making" exercise, opening up space for broader social transformations (see Kipfer 2002).

1225 Building on the preceding points, fixes embed social and cultural meaning in fixed capital and infrastructure and in turn constitute the rhythms and experiences of everyday life. This means that the success or failure of a socioecological fix rests on how well it rec-

1230 onciles the imperatives of the circulation and realization of value with those of social life more generally. Looking back, some of Harvey's earliest work is attentive to these dynamics. For instance, in a 1976 article, he wrote: "The construction of the built environment has to be seen, therefore, in the context of a struggle over a whole way of living and being" (Harvey 1976, 277). He also suggested, "under the social relations of capitalism, the built environment becomes an artifact of human labor that subsequently returns to dominate daily life" (Harvey 1976, 279). So, too, it would seem, is this spirit apparent in Harvey's more empirical work on Paris. Significantly, Harvey (1976) drew from and credited Gramsci (1971) for identifying the social projects that accompany revolutions in production as discussed at length in his notes on "Americanism and Fordism."

Marx ([1867] 1977) was certainly aware of how fixed capital transformed lived experiences. Nowhere was this clearer than in his writings on machinery and the labor process, where he discussed how the dead labor of fixed capital defines the rhythms and experiences of work for those who sell labor power in return for a wage. ${ }^{7}$ It is possible, however, to adopt a broader approach and consider the ways in which everyday life, within and beyond moments of work, is shaped by fixed capital investments in spatially explicit infrastructure. Huber's (2013) work is again exemplary, with its emphasis on the conjoined transformation of forces of production on the one hand and notions of freedom and autonomy on the other. He emphasized in particular networks of fossil-fuel-related infrastructure in U.S. landscapes, including everything from highways and gas stations to drive-through restaurants. Kaika's work is pertinent here, too, specifically her discussion of the ways in which gendered norms and experiences were transformed as water became piped into houses and apartments. Another example comes from Simon (2003) who suggested that the Civilian Conservation Corps was about more than physical infrastructure, or even labor, writing that "promoters of the New Deal agency talked about more than trees and the environment, relief and patronage ... they imagined the CCC as a way to restore the nation's flagging manhood, and virility" (81). All of this demonstrates ways in which the construction of the built environment, and thus any socioecological fix, is indeed "a struggle over a whole way of living and being."

Gramsci's relational historical materialism, together with the other works we have invoked, provides a vital resource for confronting the relationship between the formation of hegemony and the dynamics of socioecological fixes. Although O'Connor's work signals the 
potential for crises of legitimacy to be triggered by 1285 socioecological change, drawing on Gramsci, we can see more fully the ways in which relations of meaning and ideological formations are caught up in fixed capital formation and infrastructure projects. For Gramsci (1971), hegemony involves "bringing about not only a 1290 union of economic and political aims, but also intellectual moral unity, posing all the questions around which struggles rage not on a corporate but a 'universal plane"' (182). The establishment of fixed capital in response to crises unites the economic and political,

1295 but as we have tried to demonstrate in this section, at stake in such responses are broader political, cultural, and social interventions that underpin the hegemony of particular social classes and projects. Hall (1996) suggested, "we must take note of the multi-dimen-

1300 sional, multi-arena character of hegemony" (424), and our contention is that fixed capital and socioecological processes and landscapes must make the list, most certainly when considering links between crises of capital accumulation and the formation of socioecological 1305 fixes.

\section{Conclusion}

In our paired articles, we have explored the notion of the socioecological fix, and specifically, the metabolism of capital diverted into relatively enduring forms

1310 of the built environment (broadly understood). In this second article, our focus has been on deepening a metabolic perspective on fixed capital as a site of the production of nature, also arguing that socioecological fixes involve more than just bricks, mortar, and the

1315 circulation of value through socionatural relations and landscapes. Fixed capital is deeply ideological; it is produced from within and through political and cultural struggles between particular social classes and institutions, including states, and in the context of the pur-

1320 suit of hegemony. Fixed capital, in this register, gives form to and makes real ideological pillars of legitimacy, including notions of freedom, modernity, progress, and the like, notions that in turn are foundational to stitching together hegemonic social 1325 orderings via the expression of the interests of leading groups and classes as the ideals, values, and beliefs of society more generally. In as much as fixed capital is also the production of socionatures, as we have argued, our aim has been to situate socioecological fixes within

1330 the construction of hegemony. This is not to say, however, that fixed capital necessarily fixes or secures hegemonic social formations and projects in any lasting sense. Rather, our emphasis is on the ways in which the production of everyday environments through socioecological fixes helps comprise the grounds on which social struggles take place, whatever their outcomes.

Developing notions of the ways in which capitalist crises are offset materially and ideologically by new configurations of produced socionatures provides us with analytical and political tools to interrogate the political ecology of capitalist accumulation and crises thereof as they articulate with the broader politics of environmental change and everyday life. Our emphasis has been on the context-contingent and historicist character (including the role of political contestation and struggle) of capitalist crisis formation, capital switching, the production of nature, and the cultural politics of socioecological fixes. Yet we have done so in largely abstract fashion. We do indeed appreciate the considerable irony of that fact given our arguments. In our defense, the project is an outgrowth of our respective empirical and historical work to date, even if space does not allow for the elaboration of those connections. Equally, these articles originated from our appreciation of and concern about the ways in which the legitimacy of capitalism seems more and more explicitly to turn on questions raised by the politics of socioecological transformation, and conversely, about the ways in which environmentalism is increasingly becoming aligned with and expressed through the reproduction of capitalist social relations and institutions. The production of nature in the guise of fixed capital, to us, is one of the proving grounds for the fusing of environmentalism and the reproduction of capitalism. Can this fusion be sustained? There is a pressing need for the arguments in these two articles to be taken up, challenged, revised, or even dispensed with as they are worked through more careful empirical studies on actual socioecological fixes within the current conjuncture.

Many questions remain. Who wins and who loses as particular social groups and states strive to secure and contest the trajectory of landscape change animated by the diversion of capital in the built environment, including on explicitly socioecological grounds? Insofar as productive forces are built into landscapes and socioecological processes, do fixes exacerbate socioecological crisis tendencies in the long run and if so how? How do socioecological fixes rework prevailing spatial and temporal dimensions of socionatures? Are fixes undermined through bouts of devaluation and underinvestment? Or, as Castree and Christophers 
(2015) suggested, can socioecological fixes based on

1385 private capital investments (with varying degrees of state involvement) be leveraged to realize progressive ecological goals? What is the role of social movements in formulating such goals? Could this be the terrain on which alternative hegemonies are forged and realized?

\section{Acknowledgments}

Thanks to Bruce Braun for encouraging us to persist with these papers, to James McCarthy for his generosity and guidance in working us through the editorial process with the journal, and to four anonymous

1395 reviewers for their informed, detailed, and extremely helpful comments. We are grateful for formative feedback on earlier drafts from the members of the Political Economy and Political Ecology research group at the University of Toronto, and from Bram Buscher,

1400 Rob Fletcher, Alex Loftus, Geoff Mann,-and-Don Mitchell. Portions the papers were presented at the Historical Materialism 2016 meeting at York University in Toronto, and at the Socialist Studies meetings in Ottawa in 2015. We benefited from comments

1405 received in both settings. Sam Walker and Heidi Tripp provided key support as research assistants along the way. We accept responsibility for the final product, Q2 including any remaining shortcomings.

\section{2}

\section{Notes}

1410 1. Although we cannot fully address the similarities and differences between Harvey's and Gramsci's respective styles of Marxism in this article, it should be noted that Harvey drew on Gramsci's Prison Notebooks in some of his earlier work (see Harvey 1976) and more recently

1415 (Harvey 2010, 2013). Moreover, Harvey's (1985a, 2003b) more "concrete" and historical studies such as Paris, Capital of Modernity express a certain Gramscian sensibility in that cultural and political processes become constitutive of the historical geography of capi-

1420 tal accumulation and urbanization. That said, Harvey's (2014) more recent work, Seventeen Contradictions and the End of Capitalism, diverges from Gramsci's relational method, through trying to isolate "capital" from broader processes and positioning relations of difference as

1425 inconsequential to the contradictions of capital. This instinct to isolate capital can be read as un-Gramscian.

2. Here a familiar contradiction in Marx's writing appears; that is, language that clearly suggests that humans dominate nature, alongside a more a nuanced suggestion that

1430 humans "participate in nature." This tension likely cannot be resolved in the context of Marx's writing and we do not aim to do so here, but see Harvey (1996), Foster (2000), Smith ([1984] 2008), Loftus (2012), and Burkett (2014).
3. See Capital, Volume 1, particularly Chapter 16. See Murray (2004) for discussion and analysis of the significance of the contrast between formal and real subsumption in Marx.

4. This quote suggests that the formal subsumption of labor was a historical phase of surplus value production. We do not interpret Marx in that way, but the issue is also not important to the points we make here.

5. Smith's framing is offered in part as a response to Boyd, Prudham, and Schurman (2001), who emphasized the significance of biological processes in lending themselves to formal subsumption through means of enhancing biological growth processes and thus intensification (in contrast to extending the scope of production), in explicit parallel with Marx's conceptualization of the contrast between the formal (extensive) subsumption of labor and the real (intensive) subsumption of labor.

6. Debates in cultural geography and sociology related to the making and symbolic significance of landscapes is one area of literature with affinities to what we are arguing in this text. In particular, the work of Cosgrove (1984), Cosgrove and Daniels (1988), Zukin (1991), D. Mitchell (1996, 2000, 2003) and Duncan and Duncan (2003) has highlighted how questions of power, ideology, and representation are central to the making, experiences, and politics of landscapes. We have chosen to generally bracket this literature (with the exception of Mitchell) in this piece and focus on debates on political ecology, given the influence of Harvey and Smith to this field, and also on Gramsci because of his writings and others on hegemony.

7. The clearest examples of this come in Chapter 15 of Capital, Volume 1, titled "Machinery and Large-Scale Industry” (see Marx [1867] 1977, 455-636).

\section{References}

Bakker, K., and G. Bridge. 2006. Material worlds? Resource geographies and the "matter of nature." Progress in Human Geography 30 (1): 5-27.

Boyd, W., S. Prudham, and R. Schurman. 2001. Industrial dynamics and the problem of nature. Society 8 Natural Resources: An International Journal 14 (7): 555-70.

Braun, B. 2002. The intemperate rainforest: Nature, culture and power on Canada's west coast. Minneapolis: University of Minnesota Press.

. 2006. Towards a new earth and a new humanity: Nature, ontology, politics. In David Harvey: A critical reader, ed. N. Castree and D. Gregory, 191-222. Oxford, UK: Blackwell.

Buck-Morss, S. 1995. The dialectics of seeing: Walter Benjamin and the Arcades. Cambridge, MA: MIT Press.

Burkett, P. 2014. Marx and nature: A red and green perspective. Chicago: Haymarket.

Buttigieg, J. 1990. Gramsci's method. Boundary 217 (2): 60-81.

- 1992. Introduction. In Prison notebooks. Vol. 1., A. Gramsci, 1-64. New York: Columbia University Press.

Castree, D. 1995. The nature of produced nature: Materiality and knowledge construction in Marxism. Antipode 27 (1): 5-36. 


\section{tal E Class 72:5-36.}

- 2001. Marxism, capitalism, and the production of nature. In Social nature: Theory, practice, and politics, ed. N. Castree, 189-208. Oxford, UK: Blackwell.

- 2002. False antithesis? Marxism, nature and actor networks. Antipode 34 (1): 111-46.

Castree, N., and B. Christophers. 2015. Banking spatially on the future: Capital switching, infrastructure, and the ecological fix. Annals of the Association of American Geographers 105 (2): 378-86.

1505 Clapp, J. 2012. Food. Cambridge, UK: Polity.

Cosgrove, D. 1984. Social formation and symbolic landscape. London: Croom Helm.

Cosgrove, D., and S. Daniels, eds. 1988. The iconography of landscape: Essays on the symbolic representation, design, and use of past landscapes. Cambridge, UK: Cambridge University Press.

Duncan, J., and N. Duncan. 2003. Landscapes of privilege: The politics of the aesthetic in an American suburb. London and New York: Routledge.

1515 Eaton, E. 2011. On the farm and in the field: The production of nature meets the agrarian question. New Political Economy 16 (2): 247-51.

Ekers, M. 2009. The political ecology of hegemony in depression-era British Columbia, Canada: Masculinities, work and the production of the forestscape. Geoforum 40 (3): 303-15.

- 2015. A fix in the forests: Relief Labour and the production of reforestation infrastructure in depressionera Canada. Environment and Planning A 47 (12): 2537 54.

Ekers, M., and A. Loftus. 2013a. Gramsci: Space, nature and politics. In Gramsci: Space, nature and politics, ed. M. Ekers, A. Loftus, S. Kipfer, and G. Hart, 15-43. Malden, MA: Wiley-Blackwell.

$1530-2013 \mathrm{~b}$. Revitalizing the production of nature thesis: A Gramscian turn? Progress in Human Geography 37

Fontana, B. 1996. The concept of nature in Gramsci. Philosophical Forum 27 (3): 220-43.

1535 Foster, J. B. 2000. Marx's ecology: Materialism and nature. New York: Monthly Review Press.

Gandy, M. 2002. Concrete and clay: Reworking nature in New York City. Cambridge, MA: MIT Press.

Gilmore, R. 2007. Golden gulag: Prisons, surplus, crisis, and opposition in globalizing California. Berkeley: University of California Press.

Glassman, J. 2003. Rethinking overdetermination, structural power, and social change: A critique of GibsonGraham, Resnick, and Wolff. Antipode 35 (4): 678-98.

- 2007. Recovering from crisis: The case of Thailand's spatial fix. Economic Geography 83 (4): 349-70.

Graham, S., and S. Marvin. 2001. Splintering urbanism. London and New York: Routledge.

1550 Gramsci, A. 1971. Selections from the prison notebooks of Antonio Gramsci. London: Lawrence and Wishart.

-1995. Further selections from the prison notebooks. London: Lawrence and Wishart.

Hall, S. 1996. Gramsci's relevance for the study of race and (2): 234-52. studies, ed. D. Morley, 411-46. London and New York: Routledge.

Hall, S., B. Lumley, and G. McLennan. 1977. Politics and ideology: Gramsci. Cultural Studies 10:45-76.

Harvey, D. 1976. Labour, capital and class struggle around the built environment in advanced capitalist societies. Politics 8 Society 6 (3): 265-95.

- 1978. The urban process under capitalism: A framework for analysis. International Journal of Urban and Regional Research 2 (1-4): 101-31.

. 1981. The spatial fix-Hegel, Von Thunen, and Marx. Antipode 13 (3): 1-12.

- 1982. The limits to capital. Oxford, UK: Blackwell.

1985a. Consciousness and the urban experience: Studies in the history and theory of capitalist urbanization. Baltimore, MD: Johns Hopkins University Press.

- 1985b. The geopolitics of capitalism. In Social relations and spatial structures, ed. D. Gregory and J. Urry, 128-63. London: Macmillan.

- 1985c. The urbanization of capital. Oxford, UK: Blackwell.

. 1996. Justice, nature, and the geography of difference. Cambridge, MA: Blackwell.

. 2001. Globalization and the "spatial fix." Geographische Revue 2:23-30.

. 2003a. The new imperialism. Oxford, UK: Oxford University Press.

. 2003b. Paris, capital of modernity. London and New York: Routledge.

. 2010. History versus theory: A commentary on Marx's method in Capital. Historical Materialism 20 (2): $3-38$.

- 2013. A companion to Marx's Capital, Volume 2. London: Verso.

-2014. Seventeen contradictions and the end of capitalism. Oxford, UK: Oxford University Press.

Henderson, G. 1998. Nature and fictitious capital: The historical geography of an agrarian question. Antipode 30 (2): 73-118.

. 1999. California 89 the fictions of capital. New York: Oxford University Press.

- 2009. Marxist political economy. In A companion to environmental geography, ed. N. Castree, D. Demeritt, D. Liverman, and D. B. Rhoad, 266-93. Oxford, UK: Wiley Blackwell.

Heynen, N., M. Kaika, and E. Swyngedouw. 2006. In the nature of cities: Urban political ecology and the politics of urban metabolism. London and New York: Routledge.

Huber, M. 2013. Lifeblood: Oil, freedom, and the forces of capital. Minneapolis: University of Minnesota Press.

Jessop, B. 1990. State theory: Putting the capitalist state in its place. Cambridge, UK: Polity.

Johnson, L. 2015. Catastrophic fixes: Cyclical devaluation and accumulation through climate change impacts. Environment and Planning A 47 (12): 250321.

Kaika, M. 2005. City of flows: Modernity, nature, and the city. London and New York: Routledge.

Kaika, M., and E. Swyngedouw. 2000. Fetishizing the modern city: The phantasmagoria of urban technological
1560 ethnicity. In Stuart Hall: Critical dialogues in cultural 
networks. International Journal of Urban and Regional Research 24 (1): 120-38.

1620 Karriem, A. 2013. Space, ecology, and politics in the praxis of Brazil's landless movement. In Gramsci: Space, nature and politics, ed. M. Ekers, A. Loftus, S. Kipfer, and G. Hart, 83-103. Malden, MA: Wiley-Blackwell.

Katz, C. 2001. Vagabond capitalism and the necessity of social reproduction. Antipode 33 (4): 709-28.

Kipfer, S. 2002. Urbanization, everyday life and the survival of capitalism: Lefebvre, Gramsci and the problematic of hegemony. Capitalism, Nature, Socialism 13 (2): $117-49$.

1630 . 2008. Hegemony, everyday life, and difference: How Lefebvre urbanized Gramsci. In Space, difference, and everyday life: Reading Henri Lefebure, ed. K. Goonewardena, S. Kipfer, R. Milgrom, and C. Schmid, 193-211. London and New York: Routledge.

1635 Kloppenburg, J. R. 1988. First the seed: The political economy of plant biotechnology, 1492-2000. Cambridge, UK: Cambridge University Press.

Lefebvre, H. 1991. The production of space. Oxford, UK: Blackwell.

1640 Loftus, A. 2009a. Intervening in the environment of the everyday. Geoforum 40 (3): 326-34.

2009b. The thesis on Feuerbach as a political ecology of the possible. Area 41 (2): 157-66.

-. 2012. Everyday environmentalism. Minneapolis: University of Minnesota Press.

- 2013. Gramsci, nature, and the philosophy of praxis. In Gramsci: Space, nature and politics, ed. M. Ekers, A. Loftus, S. Kipfer, and G. Hart, 178-96. Malden, MA: Wiley Blackwell.

1650 Maher, N. 2008. Nature's new deal. Oxford, UK: Oxford

Q3 University Press

Mann, G. 2009. Should political ecology be Marxist? A case for Gramsci's historical materialism. Geoforum 40 (3): $335-44$.

1655 Marx, K. [1858]1973. Grundrisse: Foundations of the critique of political economy (rough draft). Harmondsworth, UK: Penguin.

—. [1867]1977. Capital, Volume 1. New York: Vintage. . [1885]1978. Capital, Volume 2. New York: Penguin.

1660 . [1845]1998. Thesis on Feurebach. In The German ideology, K. Marx, 569-74. Amherst, NY: Prometheus.

McCarthy, J. 2015. A socioecological fix to capitalist crisis and climate change? The possibilities and limits of renewable energy. Environment and Planning A 47 (12): 2485-2502.

1665

Mitchell, D. 1996. The lie of the land: Migrant workers and the California landscape. Minneapolis: University of Minnesota Press.

- 2000. Cultural geography: A critical introduction.

$1670 \quad$ Malden, MA: Blackwell. landscape-California living, California dying. In Handbook of cultural geography, ed. K. Anderson, 23348. London, UK: Sage.

1675 Mitchell, T. 2002. The rule of experts: Egypt, techno-politics, modernity. Berkeley: University of California Press.

Moore, J. 2011. Transcending the metabolic rift: A theory of crises in the capitalist world ecology. The Journal of Peasant Studies 38 (1): 1-46.
- 2015. Capitalism in the web of life. London: Verso.

Morton, A. D. 2007. Unravelling Gramsci: Hegemony and passive revolution in the global political economy. Ann Arbor, MI: Pluto Press.

Murray, P. 2004. The social and material transformation of production by capital: formal and real subsumption in Capital, Volume 1. In The constitution of capital, ed. R. Bellofiore and N. Taylor, 243-73. Houndmills, UK: Palgrave Macmillan.

O'Connor, J. 1997. Natural causes: Essays in ecological Marxism. New York: Guilford.

Patel, R. 2013. The long Green Revolution. Journal of Peasant Studies 40 (1): 1-63.

Prudham, S. 2003. Taming trees: Capital, science, and nature in Pacific Slope tree improvement. Annals of the Association of American Geographers 93 (3): 636-56.

-2005. Knock on wood: Nature as commodity in Douglas-fir country. London and New York: Routledge.

Rehmann, J. 2014. Theories of ideology: The powers of alienation and subjection. Chicago: Haymarket.

Safi, M. 2016. India plans nearly $60 \%$ of electricity capacity from non-fossil fuels by 2027. The Guardian 22 December 2014. https://www.theguardian.com/world/2016/ dec/21/india-renewable-energy-paris-climate-summittarget?CMP=Share_iOSApp_Other (last accessed 5 January 2017).

Santucci, A., G. Di Mauro, and S. Engel-Di Mauro. 2010. Antonio Gramsci [Antonio Gramsci, 1891-1937]. New York: Monthly Review Press.

Sayer, D. 1987. The violence of abstraction: The analytic foundations of historical materialism. Oxford, UK: Blackwell.

Simon, B. 2003. "New men in body and soul": The Civilian Conservation Corps and the transformation of male bodies and the body politic. In Seeing nature through gender, ed. V. Scharff, 80-102. Lawrence: University Press of Kansas.

Smith, N. 1996. The production of nature. In Future natural: Nature science and culture, ed. G. Robertson, 35-52. London and New York: Routledge.

- 1998. Nature at the millennium: Production and reenchantment. In Remaking reality, ed. B. Braun, 27185. London and New York: Routledge.

. 2007. Nature as an accumulation strategy. In Coming to terms with nature: Socialist register 2007. Vol. 14, ed. L. Panitch and C. Leys, 17-36. New York: Monthly Review Press.

[1984]2008. Uneven development: Nature, capital and the production of space. Athens: University of Georgia Press.

Swyngedouw, E. 1999. Modernity and hibridity: Nature, regeneracionismo, and the production of the Spanish waterscape, 1890-1930. Annals of the Association of American Geographers 89 (3): 443-65.

—. 2000. The Marxian alternative: Historical-geographical materialism and the political economy of capitalism. In A companion to economic geographer, ed. E. Sheppard and T. J. Barnes, 41-59. Oxford, UK: Blackwell.

- 2006. Circulation and metabolisms: (Hybrid) natures and (cyborg) cities. Science as Culture 15 (2): 105-21. 
2007. TechnoNatural revolutions: Scalar politics and Franco's wet dream for Spain, 1939-1975. Transactions of the Institute of British Geographers 32 1745 (1): 9-28.

2015. Liquid power: Water and contested modernities in Spain, 1898-2010. Cambridge, MA: MIT Press.

Thomas, P. D. 2009. The Gramscian moment: Philosophy, hegemony and Marxism. Leiden, The Netherlands: Brill.

1750 Wainwright, J. 2013. On the nature of Gramsci's conceptions of the world. In Gramsci: Space, nature and politics, ed. M. Ekers, A. Loftus, S. Kipfer, and G. Hart, 161-77. Malden, MA: Wiley-Blackwell.

Walker, R. 2004. The conquest of bread: 150 years of agribusiness in California. New York: New Press.

Weiss, T. 2007. The global food economy: The battle for the future of farming. Halifax, NS, Canada: Fernwood.

Williams, R. 1973. The country and the city. New York: Oxford University Press.

1760 Wilson, A. 1992. The culture of nature: North American landscape from Disney to the Exxon Valdez. Cambridge, MA: Blackwell.

Zalik, A. 2015. Resource sterilization: Reserve replacement, financial risk, and environmental review in Canada's tar sands. Environment and Planning A 47 (12): 2446- 1765 64.

Zukin, S. 1991. Landscapes of power: From Detroit to Disney World. Berkeley: University of California Press.

MICHAEL EKERS is an Assistant Professor in the Department of Human Geography at the University of Toronto, Scarborough. E-mail: michael.ekers@utsc.utoronto.ca. His current research draws on debates on the political economy of nature and agrarian change to understand the financialization of forestlands in British Columbia, Canada, and the role and significance of interns and apprenti-in staffing agro-ecological farms in Ontario, Canada.

SCOTT PRUDHAM is a Professor in the Department of Geography and Planning, cross-appointed to the School of the Environment at the University of Toronto. E-mail: scott.prudham@utoronto.ca. His research interests lie at the intersection of political economy and environmental change, with a current focus on long-term agrarian transformation, village-level production cooperatives, and conjoined socioenvironmenta shange in the wine sector of Languedoc, France. 